\title{
Detection of OXA-51 Carbapenemase Gene in Klebsiella pneumoniae: A Case Report and a New Dimension on Carbapenemase Resistance
}

\author{
Budak S ${ }^{1}$, Aktaş $Z^{2 *}$, Oncul $\mathrm{O}^{1}$, Acar $\mathrm{A}^{1}$, Ozyurt $\mathrm{M}^{3}$, Turhan $\mathrm{V}^{1}$ and Gorenek $\mathrm{L}^{1}$
}

${ }^{1}$ Department of Infectious Disease and Clinical Microbiology, Gulhane Military Medical Academy Haydarpasa Training Hospital, Uskudar-Istanbul 34668, Turkey ${ }^{2}$ Department of Clinical Microbiology, Istanbul Faculty of Medicine, Istanbul University, Istanbul, Turkey

${ }^{3}$ Department of Clinical Microbiology, Gulhane Military Medical Academy Haydarpasa Training Hospital, Uskudar-Istanbul, Turkey

\begin{abstract}
We investigated the occurence of genes associated with the production of carbapenem hydrolysing carbapenemases in Klebsiella pneumoniae isolates recovered from ICU patient. Antimicrobial susceptibility testing was performed and resistance genes were characterized by PCR amplification and sequencing. The Modified Hodge Test (MHT), MBL E-test, EDTA and aminophenylboronic acid (APBA) combined disk diffusion method, and a disk enzymatic assay were performed for the screening of carbapenemases. MICs of carbapenems were as follows ( $\mathrm{mg} / \mathrm{L}$ ) ertapenem 8 , meropenem 1 , imipenem 0.25 and doripenem 0.5 . The isolate demonstrated positive results in the ESBL, EDTA and APBA combined tests, and disk enzymatic assay. PCR and sequencing revealed the presence of bla ${ }_{\mathrm{OXA}-51}$ and bla ${ }_{\mathrm{CTX}-\mathrm{M}-15}$ beta-lactamase genes. Plasmids were not transferred to recipient E.coli by conjugation and transformation. In conclusion, we report on the first detection of the OXA-51 harboring K.pneumoniae isolate and co-produced a CTX-M-15 $\beta$-lactamase.
\end{abstract}

Keywords: Klebsiella pneumoniae; OXA-51 carbapenemase; Carbapenems; CTX-M-15 $\beta$-lactamase; OXA genes

\section{Introduction}

Carbapenemase related resistance against carbapenems is a serious threat and cause of treatment failure especially for patients infected with hospital strains. Carbapenem resistance was rarely reported in enteric bacteria until recent years. In Enterobacteriaceae, carbapenemases are diverse problem; these belong to molecular class B (IMP, VIM or NDM), class A (KPC) and class D (OXA-23 and OXA-48) enzymes as well as those combining AmpC enzyme or an extended-spectrum $\beta$-lactamase (ESBL) with porin loss. These carbapenemases are involved in outbreaks in various geographical regions and are increasingly reported in sporadic cases worldwide [1-6]. OXA carbapenemases are responsible for middle level carbapenem resistance mostly among Acinetobacter spp. Previously, OXA-23, OXA-24/40, OXA-58 were classified as acquired and OXA-51 was defined as chromosomal. However, in recent years, transmission of resistance via transferrable elements is shown $[7,8]$.

In the present study, we investigated the occurrence of genes associated with the production of carbapenem hydrolysing carbapenemases in Klebsiella pneumoniae isolates recovered from inpatient at Hospital, a 1000-bed training hospital located in Istanbul.

\section{Case Report}

At the end of March 2010, a 31-year-old male suffering from Miller-Fisher syndrome was admitted to Neurology intensive care unit (ICU). Nine days after his admission, he suffered from ventilatorassociated pneumonia. A strain of Acinetobacter baumannii was isolated from tracheal aspirate sample. The patient was treated with a broad spectrum beta-lactam and beta-lactamase inhibitor combination for Acinetobacter baumannii-related, ventilator-associated pneumonia. However, the patient on prolonged mechanical ventilation, another VAP was diagnosed caused by ESBL producing K. pneumoniae that was resistant to ertapenem was isolated from tracheal aspirate and blood cultures on the 25th day of stay. The patient was successively treated with colistin (10 days) for ertapenem resistant K. pneumoniae, He was discharged. in good health from the hospital 50 days after admission (Table 1).

\section{Methods}

\section{Antibiotic susceptibility testing}

The Klebsiella pneumoniae strain was identified by conventional and automated methods (VITEC2, bioMérieux France).Antibiotic susceptibility testing was performed by the disk diffusion method. The tested antibiotics were ampicillin, cefazolin, cefoxitin, ceftriaxone, cefotaxime cefepime, ceftazidime, aztreonam, amoxicilin/ clavulanic acid, imipenem, ertapenem, meropenem, trimethoprim/ sulfamethoxazol, amikacin, tobramycine and ciprofloxacin. MICs of imipenem, meropenem, ertapenem and doripenem were determined using the agar dilution method according to the recommendations of the Clinical and Laboratory Standards Institute (CLSI) [9]. ESBL production was determined by CLSI ESBL confirmatory test. Quality control testing was performed using Pseudomonas aeruginosa ATCC 27853, Escherichia coli ATCC 25922 and K.pneumoniae ATCC 700603.

\section{Phenotypic characterization}

Carbapenemases were phenotypically investigated by the modified Hodge test (MHT) using ertapenem and meropenem disks and by Metallo- $\beta$-lactamase (MBL) Etest, a combined disk test using a meropenem $(10 \mu \mathrm{g})$ and ertapenem $(10 \mu \mathrm{g})$ disks which were supplemented with $292 \mu \mathrm{g}$ of EDTA, $400 \mu \mathrm{g}$ of aminophenylboronic acid (APBA) for metallo-beta-lactamases (MBL) and KPC [9-12]. ESBL production was determined by the double-disk synergy test

*Corresponding author: Zerrin Aktas, Department of Clinical Microbiology Istanbul Faculty of Medicine, Istanbul University,Capa-34390, Istanbul, Turkey, Tel: 009021241420 00-32279; Fax: 009021241420 37; E-mail: aktaszerrin@ yahoo.com

Received July 09, 2013; Accepted August 06, 2013; Published August 08, 2013 Citation: Budak S, Aktaş Z, Oncul O, Acar A, Ozyurt M, et al. (2013) Detection of OXA-51 Carbapenemase Gene in Klebsiella pneumoniae: A Case Report and a New Dimension on Carbapenemase Resistance. J Mol Genet Med 7: 63 doi:10.4172/1747-0862.1000063

Copyright: (c) 2013 Budak S, et al. This is an open-access article distributed under the terms of the Creative Commons Attribution License, which permits unrestricted use, distribution, and reproduction in any medium, provided the original author and source are credited 


\begin{tabular}{|l|c|l|l|l|l|l|l|}
\hline & Gender & $\begin{array}{l}\text { Age } \\
\text { (year) }\end{array}$ & $\begin{array}{l}\text { Length } \\
\text { stay }\end{array}$ & $\begin{array}{l}\text { of Infections due to } \\
\text { A.baumannii }\end{array}$ & $\begin{array}{l}\text { Day of isolation of } \\
\text { A.baumannii }\end{array}$ & $\begin{array}{l}\text { Day of isolation } \\
\text { of } \text { K.pneumoniae }\end{array}$ \\
\hline Patient & M & 31 & 50 & VAP & & $\begin{array}{l}\text { Infections } \\
\text { due to Enteric } \\
\text { bacteria }\end{array}$ \\
\hline
\end{tabular}

NOTE: M;male, VAP; ventilator-associated pneumonia.

Table 1: Clinical features of patient and isolates.

(DDST). In addition, a disk enzymatic assay was performed to detect carbapenemase production [13].

\section{Genotypic characterization}

The presence of carbapenemase-encoding genes was investigated by polymerase chain reaction (PCR) and sequencing. Genes encoding production of serine carbapenemases $\left(b l a_{\mathrm{KPC}}\right)$, Class B $\left(b l a_{\mathrm{IMP}}, b l a_{\mathrm{VIM}}\right.$, $\left.b l a_{\mathrm{NDM}}, b l a_{\mathrm{SPM}}, b l a_{\mathrm{SIM}}\right)$, OXA beta lactamases genes ( $b l a_{\mathrm{OXA}-23-\mathrm{like}}$ $b l a_{\text {OXA24like }}, b l a_{\text {OXA51-like }}, b l a_{\text {OXA-58-like }}$ and $b l a_{\text {OXA-48 }}$ ) were analysed with a set of primers that amplify specific segments of individual beta-lactamases [14-20]. In addition, several extended-spectrum $\beta$-lactamases (PER-1, TEM, SHV and CTX-M) and acquired AmpC and Qnr genes ( $q n r A$, $q n r B, q n r S$ ) were investigated by PCR [21-26]. For the detection of class 1 integron cassettes, integron PCR was performed with primers 5 ' CS and $3^{\prime}$ CS, as described previously [27]. PCR products were analysed by electrophoresis in a $1.5 \%$ agarose gel containing $0.5 \mathrm{mg} / \mathrm{L}$ ethidium bromide at $120 \mathrm{~V}$ for 60 minute.

\section{Plasmid analysis}

Plasmid DNA extraction was attempted by the Kado Liu method [28]. Plasmid extracts were subsequently analysed by electrophoresis on a $0.7 \%$ agarose gel at $100 \mathrm{~V}$ for 4 hours using the plasmids extracted from $E$. coli V517 as the standard marker.

\section{Transfer of resistance}

Conjugation was performed using Escherichia coli $\mathrm{J} 53 \mathrm{Azt}^{\mathrm{R}}$ as the recipient strain. Mac Conkey and EMB agar plates supplemented with sodium azide $(100 \mathrm{mg} / \mathrm{L})$, ceftazidime $(0.5 \mathrm{mg} / \mathrm{L})$ and imipenem $(0.125$ $\mathrm{mg} / \mathrm{L})$ were used. Transformants were selected on Mueller-Hinton agar plates supplemented with $100 \mathrm{mg} / \mathrm{L}$ ampicilline, $2 \mathrm{mM}$ IPTG and 2\% X-galactose and screened to harbor corresponding OXA-51 and CTX-M-15 genes multiplex PCR assay.

\section{Results}

K.pneumoniae isolate was resistant to all $\beta$-lactams including ertapenem, to all aminoglycosides, to fluoroquinolones and to trimethoprim/sulfamethoxazol (Table 2). MICs of carbapenems were as follows $(\mathrm{mg} / \mathrm{L})$ ertapenem 8 , meropenem 1, imipenem 0.25 and doripenem 0.5 . It was susceptible to tigecycline and colistin (MICs of $0.5 \mu \mathrm{g} / \mathrm{ml}$ for both). The isolate demonstrated positive results in the ESBL, EDTA and APBA combined tests, and disk enzymatic assay. However, no KPC and MBL genes were detected. Acquired AmpC-type beta-lactamases and Qnr genes were not found. PCR and sequencing revealed the presence of, $b l a_{\mathrm{OXA}-51}$ and $b l a_{\text {CTX-M-15 }}$ beta-lactamase genes. Plasmid analysis indicated the presence of two plasmids (40 and 1.2 $\mathrm{kb})$.

\section{Transfer of resistance}

Plasmids extracted $K$. pneumoniae strain were not transferred to recipient $E$. coli by conjugation. Transforming or transconjugant harbouring the $b l a_{\mathrm{OXA}-51}$ gene were not obtained, which could have suggested a chromosomal location of gene.

\section{Discussion}

Reports in the United States and Europe point out the major problem caused by enteric bacteria with metallo-beta-lactamase (MBL) and KPC related carbapenem resistance [1,3-6]. The emergence and the spread of acquired carbapenem-hydrolysing class D beta-lactamases (CHDLs) have been well documented worldwide. There are nine major subgroups of OXA carbapenemases, based on amino acid homologies in Gram negative bacteria. Subgroups 1 (OXA-23-like), 2 (OXA-24-like), 3 (OXA-51-like) and 4 (OXA-58) frequently detected A. baumannii [29]. The plasmid-mediated OXA-48 enzyme, which forms the sixth subgroup, has been found primarily in K. pneumoniae, E. coli, C. freundii and E. .cloacae $[19,30]$. Among the genes encoding OXA-type carbapenemases; $b l a_{\mathrm{OXA}-23}, b l a_{\mathrm{OXA}-40}$ and $b l a_{\mathrm{OXA}-58}$ found in A. baumannii and $b l a_{\mathrm{OXA}-48}$ found in K. pneumoniae are plasmid-borne, while OXA51 may be naturally occurring in A. baumannii. However, a plasmidborne ISAba1-bla(OXA-51)-like gene has recently been identified in Acinetobacter genomic species 13TU and in several A.baumannii isolates $[7,8]$. With regard to the mechanism of carbapenem resistance in Turkey, KPC gen was not detected in any of the studied isolates. In contrast, the genes encoding CHDLs (OXA-51, OXA-23, OXA51) were detected in multidrug resistant Acinetobacter spp in several centers. In addition, OXA-48 carbapenemase is not rare especially among K. pneumoniae strains isolated from hospital infections [30].

Rapid identification of carbapenemase-producing, Gram-negative species is crucial for timely implementation of infection control measures. A previous survey carried out in our hospital in 2010, demonstrated that the $b l a_{\mathrm{OXA}-23}$ and $b l a_{\mathrm{OXA}-58}$ genes were prevalent enzymes associated with carbapenem resistance in multidrug resistant $A$. baumannii isolates. All were positive for the bla ${ }_{\mathrm{OXA}-51}$ like genes as well (unpublished data). Data concerning carbapenem resistance among Enterobacteriaceae in our hospital, the percentage of ertapenem-resistant strains of K.pneumoniae was 10\% in 2010. OXA48-type oxacillinase was found responsible for carbapenem resistance.

Carbapenemases do not always produce resistant breakpoints for carbapenems when standardized susceptibility testing methods are employed. Effective treatment and infection control depend upon the rapid and efficient identification of these isolates.

MICs of ertapenem, imipenem and meropenem are greater than 0.5 and $2.0 \mathrm{mg} / \mathrm{L}$, respectively may indicate isolates with carbapenemase production (9). Ertapenem resistance is the most sensitive screening test to detect KPC and MBL carbapenemases. On the other hand, there are a number of phenotypic tests which have been developed to detect these enzymes in Gram negative bacteria. The Modified Hodge Test (MHT) has been developed to detect both KPC and MBL enzymes, but it cannot differentiate between them; moreover, there are reports of false-positive results with CTX-M-positive or AmpC-hyperproducing Enterobacteriaceae. Several versions of boronic acid, an EDTA disk test and Etest with imipenem/imipenem with EDTA have been used for detections for MBL carbapenemases. However, no currently available test allows detection of CHDLs. In the prsent study, K.pneumoniae was found resistant to ertapenem $(8 \mathrm{mg} / \mathrm{L})$. The isolate demonstrated 
Citation: Budak S, Aktaş Z, Oncul O, Acar A, Ozyurt M, et al. (2013) Detection of OXA-51 Carbapenemase Gene in Klebsiella pneumoniae: A Case Report and a New Dimension on Carbapenemase Resistance. J Mol Genet Med 7: 63. doi:10.4172/1747-0862.1000063

Page 3 of 4

\begin{tabular}{|l|c|c|c|c|c|c|c|c|c|c|c|c|c|c|c|c|}
\hline & IP & MEM & ETP & DOR & TM & AK & FX & TX & XL & TZ & PTC & XM & AM & CPS & CT & OF \\
\hline K.pn-38 & 0.25 & 1 & 8 & 0.5 & 96 & 128 & $>256$ & $>256$ & $128 / 64$ & 48 & $256 / 4$ & $>256$ & $>256$ & 16 & $>32$ & $>32$ \\
\hline Transformant-38 & 0.25 & 0.23 & 0.16 & 0.23 & 0.38 & 1 & 1 & 0.064 & $24 / 12$ & 1 & $3 / 4$ & 4 & $>256$ & 4 & 0.032 & 0.008 \\
\hline $\begin{array}{l}\text { E.coli } \\
\text { DH10B }\end{array}$ & 0.125 & 0.16 & 0.08 & 0.12 & 0.38 & 2 & 2 & 0.094 & $3 / 1.5$ & 0.19 & $1 / 4$ & 4 & 3 & 0.016 & 0.032 & 0.16 \\
\hline $\begin{array}{l}\text { E.coli } \\
\text { DH10B (PUC19) }\end{array}$ & 0.125 & 0.16 & 0.06 & 0.12 & 0.38 & 1.5 & 1.5 & 0.047 & $6 / 3$ & 0.19 & $1 / 4$ & 2 & $>256$ & 0.016 & 0.032 & 0.047 \\
\hline
\end{tabular}

Table 2: MIC (mg/L) distribution ,of imipenem (IP), meropenem (MEM), ertapenem (ETP), doripenem (DOR) tobramisin (TM), cefotaxime (FX), amikacin (AK), ceftriaxone $(\mathrm{TX})$, amoxilline/clavulanic acid (XL) ceftazidime (TZ), piperaciliin/tazobactam (PTC), cefuroxime (CXM), ampicillin (AM), cefoperazone sulbactam (CPS), cephalotin (CT) ofloxacin (OF) for K. pneumoniae and transformant-38.

positive results in the ESBL, EDTA and APBA combine tests, and disk enzymatic assay. However, unexpected results were detected as PCR and sequencing revealed the presence of $b l a_{\text {OXA-51 }}$ gene in K.pneumoniae strain for the first time which are known to be A. baumannii-related. The isolates also possess $b l a_{\mathrm{CTX}^{-}{ }^{-} 15}$ beta-lactamase gene. Acquired AmpC-type beta-lactamases and qnr genes were not found. It is known that OXA enzymes do hydrolyse penicillins, but do not hydrolyse expanded-spectrum cephalosporin. They are responsible for low or middle level carbapenem resistance mostly among Acinetobacter spp. and are not inhibited by clavulanic acid but are inhibited by $\mathrm{NaCl}_{2}$ in vitro. In the present study, K.pneumoniae strain was found to be susceptible to imipenem meropenem and doripenem on the basis of their MICs, which raises two issues: first, carbapenem-susceptible or decreased susceptibility and intermediate susceptible isolates may go clinically undetected during routine antibacterial drug susceptibility testing, second, the clinical efficacy of imipenem on such strains is uncertain.

OXA enzymes may be widespread rapidly among various Gramnegative bacteria. The dissemination of plasmids, transposons, and integrons among bacteria and species give rise to so-called gene epidemics. Integrons have a fearsome capacity for the recruitment, spread, and expression of resistance genes, and surveys show that they are widespread among gram-negative bacteria [6,7]. Chromosomal mediation of bla $a_{\mathrm{OXA}-23}$ has been described previously for Proteus mirabilis [1].

In the present study, the patient firstly infected MDR- $A$. baumannii and treated with a broad spectrum beta-lactam and betalactamase inhibitor combination for A. baumannii-related, VAP. However, 15 days later, a ertapenem resistant $K$. pneumoniae isolate recovered from the same patient with VAP. We suggest that $A$. baumannii which possesses OXA-51 gene (data not shown) may be a source of carbapenem hydrolyzing oxacillinases. These gene may have been inserted in the chromosome probably by genetic events of recombination, cointegration, or transposition in vivo. After repeated attempts, conjugation experiments failed to demonstrate the transferability of plasmids in the strain. However, PCR also detected the presence of class 1 integrons (>1300 bp) for K.pneumoniae. and it was concluded that there were also other risk factors for antimicrobial resistance such as prior antibiotic treatment, ICU admission and severe underlying diseases.

OXA-48-producing K. pneumoniae strains have been identified also in the same hospital during the same period of time. Affected wards were cleaned daily appropriate disinfectant, universal contact precautions were applied and there were three times of education clinical staff in affected wards. Environmental screening was implemented once a week. Within 24 hours after admission, rectal swabs or stool specimens were collected from patients for identification of carbapenem-resistant Enterobacteriaceae.

In conclusion, our report affirms the first detection of the OXA51 harboring K. pneumoniae isolate and co-produced a CTX-M-15 $\beta$-lactamase. As it has already mentioned above, due to the fact that OXA-beta-lactamases remains difficult to detect by phenotypic tests, enhanced surveillance and rapid identification are essential. The ability to limit the spread of these pathogens will require effective laboratory screening methods to quickly identify patients infected with these organisms. Laboratories will need new tools, perhaps molecular techniques in order to make the process quicker and more accurate. It is highly significant to immediately introduce specific infection control measures in hospital settings in order to limit the nosocomial spread of these strains.

\section{References}

1. Bonnet R, Marchandin H, Chanal C, Sirot D, Labi Ra, et al. (2001) Chromosome encoded class D beta-lactamase OXA-23 in Proteus mirabilis. Antimicrob Agents Chemother 46: 2004-2006.

2. Hsueh PR (2010) New Delhi Metalobeta-laktamase1(NDM1) an emerging threat amoung Enterobacteriaceae. J Formos Med Assoc 109: 685-687.

3. Ho J, Tambyah PA, and Paterson DL (2010) Multiresistant Gram-negative infections: a global perspective. Curr Opin Infect Dis 23: 546-553.

4. Queenan AM, Bush K (2007) Carbapenemases the Versatil beta-lactamases. Clin. Microbiol Rev 20: 440-458.

5. Rasheed JK, Biddle JW, Anderson KF, Washer L, Chenoweth C, et al. (2008) Detection of the Klebsiella pneumoniae Carbapenemase Type 2 CarbapenemHydrolyzing Enzyme in Clinical Isolates of Citrobacter freundii and K. oxytoca Carrying a Common Plasmid. J Clin Microbiol 46: 2066-2069.

6. Walsh TR (2010) Emerging carbapenemases: a global perspective. Int J Antimicrob Agents 36: 8-14.

7. Chen TL, Lee YT, Kuo SC, Hsueh PR, Chang FY, et al. (2010) Emergence and distribution of plasmids bearing the bla ${ }_{\text {ona }}$ gene with an upsteram ISAba1 in Carbapenem-resistant Acinetobacter baumannii isolates in Taiwan. Antimicrob Agents Chemother 54: 4575-4581.

8. Lee YT, Turton JF, Chen TL, Wu RC, Chang WC, et al. (2009) First identification

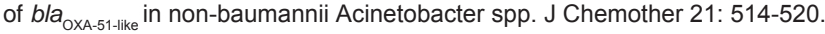

9. Clinical and Laboratory Standards Institute. M100-S20: performance standards for antimicrobial susceptibility testing; June update. 2010, CLSI, Wayne, PA.

10. Doi Y, Potoski BA, Adams-Haduch JM, Sidjabat HE, Pasculle AW (2008) Simple disk-based method for detection of Klebsiella pneumoniae carbapenemasetype beta-lactamase by use of a boronic acid compound. J Clin Microbiol 46: 4083-4086.

11. Giske CG, Gezelius L, Samuelsen Ø, Warner M, Sundsfjord A (2011) A.sensitive and specific phenotypic assay for detection of metallobeta-lactamases and $\mathrm{KPC}$ in Klebsiella pneumoniae with the use of meropenem disks supplemented with aminophenylboronic acid, dipicolinic acid and cloxacilin. Clin Microbiol Infect 17: 552-556.

12. Tsakris A, Poulou A, Pournaras S, Voulgari E, Vrioni G, et al. (2010) A simple phenotypic method for the differentiation of metallo-beta-lactamases and class 
Citation: Budak S, Aktaş Z, Oncul O, Acar A, Ozyurt M, et al. (2013) Detection of OXA-51 Carbapenemase Gene in Klebsiella pneumoniae: A Case Report and a New Dimension on Carbapenemase Resistance. J Mol Genet Med 7: 63. doi:10.4172/1747-0862.1000063

Page 4 of 4

A KPC carbapenemases in Enterobacteriaceae clinical isolates. J Antimicrob Chemother 65: 1664-1671.

13. Endimiani A, Perez F, Bajaksouzian S, Windau AR, Good CE, et al. (2010) Evaluation of Updated Interpretative Criteria for Categorizing Klebsiella pneumoniae with Reduced Carbapenem Susceptibility. J Clin Microbiol 18: 4417-4425.

14. Aktaş Z, Kayacan CB (2008) Investigation of metallo-beta-lactamase producing strains of Pseudomonas aeruginosa and Acinetobacter baumannii by E-test disk synergy and PCR. Scand Journal Infect Dis 40: 320-325.

15. Doumith M, Warner M, Weinbren M, Livermore DM, Woodford $N(2008)$ Dissemination of a novel metallo $\beta$-lactamase, NDM-1 (MIM-1) in diverse Enterobacteriaceae in the UK. 48th ICAAC and 48th IDSA Meeting. Programme and abstract book C-105, Boston, USA.

16. Endimiani A, Carias LL, Hujer AM, Bethel CR, Hujer KM, et al. (2008) Presence of plasmid-mediated quinolone resistance in Klebsiella pneumoniae isolates possessing blaKPC in the United States. Antimicrob Agents Chemother 52: 2680-2682.

17. Ellington M, Kistler JJ, Livermore DM, and Woodford N (2007) Multiplex PCR for rapid detection of genes encoding acquired metallo- $\beta$-lactamases. J Antimicrob Chemother 59: 321-322.

18. Fiett J, Baraniak A, Mrówka A, Fleischer M, Drulis-Kawa Z, et al. (2006) Molecular epidemiology of acquired metallobeta-lactamase producing bacteria in Poland. Antimicrob Agents Chemother 50: 880-886.

19. Poirel L, Hêritier C, Tolun V, Nordmann P (2004) Emergence of OxacillinaseMediated Resistance to Imipenem in Klebsiella pneumoniae. Antimicrob Agents Chemother 48: 15-22.

20. Woodford N, Ellington MJ, Coelho JM, Turton JF, Ward ME, et al. (2006) Multiplex PCR for genes encoding prevalent OXA carbapenemases in Acinetobacter spp. Int J Antimicrob Agents 27: 351-353.

21. Cattoir V, Poirel L, Rotimi V, Soussy CJ, Nordmann P (2007) Multiplex PCR for detection of plasmid-mediated quinolone resistance. qnr genes in ESBL- producing enterobacterial isolates. J Antimicrob Chemother 60: 394-397.

22. Gniadkowski M, Schneider I, Jungwirth R, Hryniewicz W, Bauernfeind A (1998) Ceftazidime resistant Enterobacteriaceae isolates from three Polish hospitals: identification of three novel TEM and SHV-5-type extended-spectrum betalactamases. Antimicrob Agents Chemother 42: 514-520.

23. Karim A, Poirel L, Nagarajan S, Nordmann P (2001) Plasmid-mediated extended-spectrum beta-lactamase (CTXM-3 like) from India and gene association with insertion sequence ISEcp 1. FEMS Microbiology Lett 201 : 237-241.

24. Nordmann P, Ronco E, Naas T, Duport C, Michel-Briand Y, et al. (1993) Characterization of a novel extended-spectrum beta-lactamase from Pseudomonas aeruginosa. Antimicrob Agents Chemother 37: 962-969.

25. Pérez-Pérez FJ, Hanson ND (2002) Detection of plasmid-mediated AmpC beta-lactamase genes in clinical isolates by using multiplex PCR. J Clin Microbiol 40: 2153-2162.

26. Poirel L, Thomas I, Naas T, Karim A, Nordmann P (2000) Biochemical sequence analyse of GES-1, a novel class A extended-spectrum beta-lactamase, and the class 1 integron In52 from Klebsiella pneumoniae. Antimicrob Agents Chemother 44: 622-632.

27. Lévesque C, Piché L, Larose C, Roy PH (1995) PCR mapping of integros reveals several novel combinations of resistance genes. Antimicrob Agents Chemother 39:185-191.

28. Kado CI, LIu ST (1995) Rapid Procedure for Detection and Isolation of Large and Small Plasmids. J Bacteriol 145: 1365-1373.

29. Walther-Rasmussen J, Høiby N (2006) OXA type Carbapenemases. J Antimicrob Chemother 57: 373-383.

30. Aktaş Z, Kayacan CB, Schneider I, Can B, Midilli K (2008) Carbapenem hydrolyzing oxacilinase, OXA-48, persists in Klebsiella pneumoniae in Istanbul, Turkey. Chemotherapy 54: 101-106. 